\title{
Think about the Scope of Democracy from a Capacity Perspective
}

\section{Vargas García TV*}

Universidad Autónoma del Estado de México, México

*Corresponding author: Tamara Viridiana Vargas García, Universidad Autónoma del Estado de México, C. Cerro de Coatepec s/n, Ciudad Universitaria, 50110 Toluca de Lerdo, México, Tel: 7225454437; Email: tamaravargas1807@gmail.com

\section{Research article}

Volume 4 Issue 4

Received Date: November 21, 2021

Published Date: December 17, 2021

DOI: $10.23880 /$ phij-16000209

\section{Abstract}

Amartya Sen's capacity has an impact on the duties and responsibilities of human beings since it implicitly contains the power to show asymmetries of various social nature, for example: natural resources, animals, situation of exclusion, vulnerability, democracy, among others. Consequently, the capacity can be understood from a way of being it allows it to adequately perform its function and know the impact with the context of the person. The concept of capacity offers a much broader possibility of understanding democracy, that is, thinking about it and exercising it from this perspective.

Keywords: Democratic capacity; Human being; Freedom; Ethical and economy

\section{Democratic Capacity}

If it is intended to reflect on democracy from a capacity approach. In this approach democracy would cease to be an instrumental tool to be a virtue; according to the Stagirite, virtue rests in a way of being "selective, it consists of an intermediate position for us, determined by reason and as determined by reason prudent man"1, following the author's logic, refers to the right means, in other words, it is about finding a balance in ourselves in order to avoid excess or defect $^{2}$ and not in things, for example: Hate speeches issued by some political leaders that have been heard repeatedly in the media cannot appeal to freedom of expression and therefore for the sake of democracy, because in the end hatred appeals to its perversion, that is, it is mean in itself.

If democracy is considered from the perspective of capacity, so that it is understood as a way of being, it allows "man to be good and thanks to whom he will perform well his

1 Aristóteles, Ética Nicomáquea II,6, México: Editorial Porrúa S. A, (24aㅡ ed), 2016, p.30.

2 Ibidem, p.29. work $^{\prime \prime}$, following Aristotelian logic this is possible because there is an ethical responsibility of the person towards the democratic capacity.

This viability would originate through the will of the human being. The will requires that the person participate and be aware at all times of the choice to be made and therefore of the act / action to be carried out. It is important to note that the choice may be impregnated with humanity or malevolence, however, in the face of such a scenario it may be thought that when the person chooses, a problem of opposites arises, that is, what could be good or bad could depend on the perspective, Consequently, the question arises, what is it that allows us to judge which choice is based on goodness or malice? Returning to Aristotelian thought, goodness is identified when it is "always palatable for itself, and never for something else" ${ }^{4}$, for example: "healthy things are what they really are"5, so processed food is not healthy in itself despite having a great marketing campaign, moving on to the issue that concerns democracy is true or tends

\footnotetext{
3 Idem.

4 Ibidem, p.10.

5 Ibidem, p.44.
} 


\section{Philosophy International Journal}

to goodness in itself, for this reason, one cannot speak of democracy when selecting the information that will appear in the media - censorship-. Nevertheless, democratic capacity does highlight the desirable in reciprocity with virtue, this is when the human being is responsible and does not live a fantasy of good under this vision the choice of him will not be determined by what is pleasant.

When the human being is aware of having capacity, it will be focused on their assertiveness because the exercise of the election occurs through the media, for example: if democracy is to flourish, each of the elections must be founded in encouraging citizen participation, ethical training of citizens, creating adequate public policies, adequate administration of justice and so on. Therefore, the democratic capacity falls on the human being because is impregnated with the choice that "is accompanied by reason and reflective comparison". ${ }^{6}$

According to Aristotle "freedom is fundamental principle of the democratic constitution"7, therefore, the democratic capacity should not exclude the idea from Stagirite's perspective, he emphasizes two references. The first has to do with a political freedom, that is, it indicates to be governed and govern by turns ${ }^{8}$, this political freedom opens the opportunity among the citizens to alternate obedience or command, this is of utmost importance in the order of a society because when the roles are reversed it allows them to be improved since they allow the recognition of the other, definitely, the empathy that would have to arise between citizens is glimpsed to better understand the problems that arise within the society - city or polis as Aristotle calls it - and thus adapt public policies, justice, people's rights, to name a few.

The second is that "live as you please, for the simple fact that the slave does not live as he wants" in other words, it is living according to your own will, which leads to individual and social freedom, freedom of expression, self-realization, possibility to choose, opportunities without neglecting respect for others and keeping the common good in mind.

From the Senian perspective, freedom in democratic capacity is relevant due to it allows us to know how feasible the styles and ways of life that one want is, in addition, through freedom, individual and social commitment and concern is expanded in the face of the inequalities that arise

\footnotetext{
6 Ibidem, p.42.

7 Aristóteles, Política IV,1, México: Editorial Porrúa S. A, (24ae ed), 2016, p.355.

8 Idem.

9 Idem.
}

in the process to reach a standard of living. ${ }^{10}$

Amartya Sen envisions that attention should be paid to the idea of freedom because there are approaches to be analyzed. The first is the aspect of opportunity, here only the achievement is recognized, in other words, it focuses on the end that has been obtained regardless of the process or means that were selected to achieve it, nonetheless, in this aspect it can be reflect on what is obtained - the culmination effect - and analyze how the person reaches the culmination - comprehensive effect. The second is the process aspect, it studies why those means were chosen. ${ }^{11}$

The breadth of freedom it allows analyzing and gathering information if a person's ability to have the life that he values is subject to obtaining the achievement / end. Furthermore, democratic capacity will not focus excessively on political freedom, otherwise, if it will treasure the freedom of each person, because from one's own will a social thought will be designed that will not be based on selfish utilitarian behavior but will be aimed at the common good, due to, the citizen will be aware that to achieve a certain achievement the existence or lack of means are important and that they are not subject to monetary factors. Freedom would help to express and defend the satisfaction of different alternatives for the development of personal and social capacity which are not limited to economic and political needs.

To illustrate the above, in the study of famines carried out by Amartya Sen, he establishes that the phenomenon of lack of food can be prevented because there is a democratic system, the government takes preventive measures besides it is difficult to ignore the criticisms of its inhabitants, since this translates into losing not only elections, but also the image of the country abroad due to there is a flow of public information. ${ }^{12}$ With this example, it is shown that when freedom has been valued in the democracy, social catastrophes can be avoided, since citizens have understood that they have capacities of various kinds, which have repercussions towards the democracy's development goes beyond one aspect of merely instrumental political culmination -exercise of the vote-, moreover, the government has understood there is indeed a reciprocity between inhabitants because from the criticisms there is a gap to take appropriate measures before the problem also the media have the possibility of exposing censorship.

\footnotetext{
10 Sen, Amartya, La idea de la justicia, México: Taurus: Santillana ediciones generales, (1 $\stackrel{\text { a }}{\text { ed), }} 2010$.

11 Sen, Amartya, La idea de la justicia, México: Taurus: Santillana ediciones generales, (1ํㅡㄹ ed), 2010.

12 Sen, Amartya, El valor de la democracia, España: El viejo topo, (s.e), 2006 .
} 
In the contemporary world it is more than evident the great role that mercantilism plays - driven by the business sector and protected by the State-; the problem is that it has led to an extremism of domination: "the appropriation of natural resources - and in the case of medicines and food, their appropriation through patents- $-{ }^{13}$ From a perspective of democratic capacity, the private appropriation of public resources and essential goods is an atrocity since it is endangering freedom of access by conditioning it "by setting a patent on the use of a product that was previously open and free has become available. a market price"14; justice and equality are also upset because "commodification, in turn, has made a difference, a barrier and a gulf between those who can afford the commodity and those who cannot". ${ }^{15}$

The previous illustration where the business sector is exposed, which has a close relationship with the area of the economy. Paul Samuelson and William Nordhaus in their work Economics, define that economics "is the study of how societies use scarce resources to produce valuable goods and distribute them among people". ${ }^{16}$ If the democratic capacity approach is followed, there is a very strong contradiction of the previous illustration, the very dignity of the business activity is undermined, there is no honor but rather an enrichment at the cost of causing the scarcity of natural resources and following the logic of an economic analysis, one of its main objectives is that insufficient resources should be prevented from worsening the problem.

Regarding the distribution, it is to make the resources reach most of the people, here you can see the relationship that exists between the economy and democracy, since there is implicitly a relationship with concepts such as: equality and justice.

In consumption it would have to focus on a free commodification; that they do not take advantage of a fraudulent situation and take advantage to cause the shortage of a good, a natural resource, and then have it on the market with a price; causing an abuse of confidence of the employer towards the final consumer since the acquisition of such a limited product will be acquired by a few, but rather it is appealed that obtaining a certain object of service is within the reach of other people.

13 Farrés, Oriol, "El trasfondo económico de la ciudadanía", en Camps, Victoria, Democracia sin ciudadanos, La construcción de la ciudadanía en las democracias liberales, Editorial Trotta, Madrid, s.e, 2010, p.48.

14 Idem.

15 Idem.

16 Samuelson, P y Nordhaus, W., Economía, Mc Graw Hill, (18ª ed), s.a, p.4.

\section{Conclusion}

Democratic capacity is not against commercialism, on the contrary, it is of importance for people's lives, since it allows obtaining products that do not necessarily have to be insufficient, it makes it possible to know cultures, discover and understand other through exchange and care of those natural resources that are in a situation of ceasing to exist.

The idea of democratic capacity is active since it allows awareness to be raised towards issues related to nature, educational training, transparency and accountability of private and public institutions, animal rights, project formulation, addressing of technology better, and so on.

It can be inferred through Amartya Sen's thought and previous examples that democratic capacity should be capable of receiving generations, allowing the growth of its own pillars because they are movements that originate from it to protect and promote the common good and hence of human development or in the words of the Stagirite human flourishing.

\section{References}

1. Aristóteles (2016) Ética Nicomáquea. 24 ${ }^{\text {th }}$ (Edn.), Editorial Porrúa SA, México.

2. Aristóteles (2016) Política. 24th (Edn.), Editorial Porrúa SA, Mexico.

3. Sen A (2006) El valor de la democracia. El viejo topo, Spain.

4. Sen A (2010) La idea de la justicia. $1^{\text {st }}$ (Edn.), Taurus: Santillana ediciones generales, Mexico, pp: 262.

5. Camps V (2010) Democracia sin ciudadanos, La construcción de la ciudadanía en las democracias liberales, Editorial Trotta, Madrid, Spain.

6. Samuelson P, Nordhaus W. Economía. 18 ${ }^{\text {th }}$ (Edn.), Mc Graw Hill. 